 \\ Spotlight on the April 12 Issue
}

Robert A. Gross, MD, PhD, FAAN

Editor-in-Chief, Neurology ${ }^{\circledR}$

Prevalence of MRI-defined recent silent ischemia and associated bleeding risk with thrombolysis

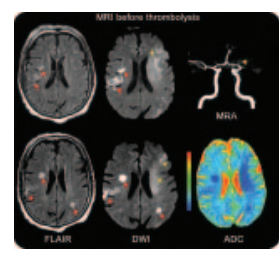

The authors analyzed the fluidattenuated inversion recovery/diffusionweighted imaging obtained before IV thrombolysis in 115 patients to search for MRI-defined recent silent ischemia (RSI). RSI was identified in $18 \%$ of pretreatment MRI; however, the presence of RSI was not associated with an increased risk of asymptomatic or symptomatic hemorrhagic transformation.

See p. 1288, Editorial, p. 1284

\section{Reduced uptake of $\left.{ }^{18} \mathrm{~F}\right] \mathrm{FDOPA}$ PET in asymptomatic} welders with occupational manganese exposure the

The authors investigated dopaminergic function using FDOPA PET in 20 asymptomatic, manganese-exposed welders, 20 subjects with idiopathic Parkinson disease, and 20 normal controls. Caudate $\mathrm{K}_{\text {is }}$ was lower in welders compared with control subjects, demonstrating that asymptomatic, manganese-exposed welders have a unique pattern of dopaminergic dysfunction.

See p. 1296

From editorialist W.R. Wayne Martin: "The study provides an excellent example of the utility of FDOPA/PET in the assessment of potential dopaminergic changes occurring in asymptomatic individuals. It is important to remember, however, that $P D$ remains a clinical diagnosis centered on the presence of the characteristic neurologic signs."

See p. 1286

Long-term follow-up of patients with neuromyelitis optica after repeated therapy with rituximab 全

The authors examined 10 patients with neuromyelitis optica who were treated up to 5 times with rituximab as a secondline therapy. They found that retreatment should be applied before reappearance of circulating $B$ cells and does provide stabilization in most patients.

See p. 1310

\begin{abstract}
fMRI language dominance and FDG-PET hypometabolism
The authors examined the association of left temporal hypometabolism with laterality of fMRI language task activation in 30 patients with temporal lobe epilepsy. They did not find evidence of impaired BOLD response in hypometabolic cortex. Regional hypometabolism appeared to be a marker for the temporal lobe dysfunction that leads to displacement of language function.

See p. 1322
\end{abstract}

\section{Long-term intellectual outcome after temporal lobe surgery} in childhood $\underline{\underline{\underline{\underline{E}}}}$

The authors report the follow-up of 42 children who underwent temporal lobe surgery. At follow-up, $86 \%$ of the surgical group were seizure-free and $57 \%$ were no longer taking antiepileptic medication. Developmental catch-up (IQ increment) was seen in children who became seizure-free after neurosurgical treatment.

See p. 1330

Folic acid supplementation prevents phenytoin-induced gingival overgrowth in children

Gingival overgrowth is a common, cosmetically and medically important adverse effect of phenytoin therapy. This study found significant reduction in the incidence of phenytoininduced gingival overgrowth in 62 participants receiving daily oral folic acid ( $0.5 \mathrm{mg} /$ day for 6 months) as compared to a placebo-control group with 58 participants.

See p. 1338

VIEWS \& REVIEWS

Autism, Alzheimer disease, and fragile X: APP, FMRP, and mGluR5 are molecular links

This review proposes a conceptual framework involving the amyloid- $\beta$ peptide, $A \beta$ precursor protein, and fragile $X$ mental retardation protein based on experimental evidence. The authors speculate that the anabolic effect of $\operatorname{sAPP} \alpha$ contributes to the state of excess that underlies fragile $X$ syndrome and autism, especially in younger children. See p. 1344

NB: Reflections for April: "The silent witness and Charcot's hat," see p. 1358. To check out other Reflections, point your browser to http://www.neurology.org. The Green Journal is celebrating an important anniversary in 2011-it is 60 years old. Check out some of the activities this week at the AAN Meeting.

Podcasts can be accessed at www.neurology.org 


\section{Neurology}

Spotlight on the April 12 Issue

Robert A. Gross

Neurology 2011;76;1283

DOI 10.1212/WNL.0b013e318216e9b7

\section{This information is current as of April 11, 2011}

\section{Updated Information \&} Services

Permissions \& Licensing

\section{Reprints}

including high resolution figures, can be found at: http://n.neurology.org/content/76/15/1283.full

Information about reproducing this article in parts (figures,tables) or in its entirety can be found online at:

http://www.neurology.org/about/about_the_journal\#permissions

Information about ordering reprints can be found online:

http://n.neurology.org/subscribers/advertise

Neurology ${ }^{\circledR}$ is the official journal of the American Academy of Neurology. Published continuously since 1951, it is now a weekly with 48 issues per year. Copyright Copyright $@ 2011$ by AAN Enterprises, Inc.. All rights reserved. Print ISSN: 0028-3878. Online ISSN: 1526-632X.

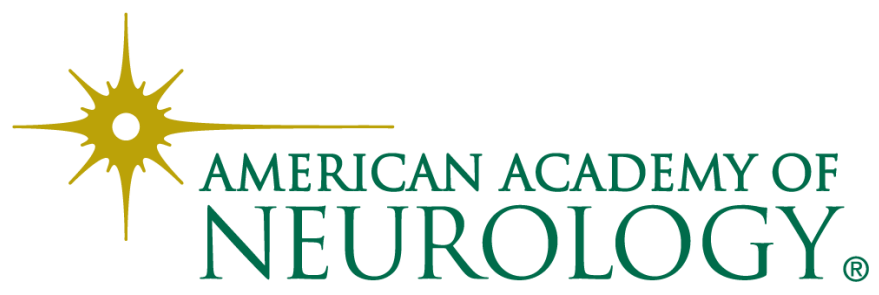

